\title{
Variability of Micronektonic Crustacean Community along a Latitudinal Transect in the Atlantic Ocean: Implications for Carbon Export
}

\author{
Javier Díaz Pérez *
}

Citation: Javier Díaz Pérez. Variability of Micronektonic Crustacean Community along a Latitudinal Transect in the Atlantic Ocean: Implications for Carbon Export. 2021, 5, x. https://doi.org/10.3390/xxxxx

Published: date

Publisher's Note: MDPI stays neutral with regard to jurisdictional claims in published maps and institutional affiliations.

\footnotetext{
(C)
Copyright: $\odot 2021$ by the authors.
Submitted for possible open access
publication under the terms and con-
ditions of the Creative Commons At-
tribution (CC BY) license (http://crea-
tivecommons.org/licenses/by/4.0/).

(C)
Copyright: $\odot 2021$ by the authors.
Submitted for possible open access
publication under the terms and con-
ditions of the Creative Commons At-
tribution (CC BY) license (http://crea-
tivecommons.org/licenses/by/4.0/).

(C)
Copyright: $\odot 2021$ by the authors.
Submitted for possible open access
publication under the terms and con-
ditions of the Creative Commons At-
tribution (CC BY) license (http://crea-
tivecommons.org/licenses/by/4.0/).

(CC)
Copyright: (C) 2021 by the authors.
Submitted for possible open access
publication under the terms and con-
ditions of the Creative Commons At-
tribution (CC BY) license (http://crea-
tivecommons.org/licenses/by/4.0/).

(CC)
Copyright: (C) 2021 by the authors.
Submitted for possible open access
publication under the terms and con-
ditions of the Creative Commons At-
tribution (CC BY) license (http://crea-
tivecommons.org/licenses/by/4.0/).

CC)
Copyright: (C) 2021 by the authors.
Submitted for possible open access
publication under the terms and con-
ditions of the Creative Commons At-
tribution (CC BY) license (http://crea-
tivecommons.org/licenses/by/4.0/).
}

Affiliation; e-mail@e-mail.com

* Correspondence: e-mail@e-mail.com

+ Presented at the 1st International Electronic Conference on Biological Diversity, Ecology and Evolution, 15-31 March 2021; Available online: https://bdee2021.sciforum.net/ (accessed on).

\begin{abstract}
The micronekton community of pelagic shrimps was studied by means of taxonomic composition, abundance and biomass analyses, across a latitudinal transect in the Atlantic Ocean from off Brazil coast $\left(15^{\circ} \mathrm{S}\right)$ to the south of Iceland $\left(55^{\circ} \mathrm{N}\right)$. Total abundance and biomass were hauled by Mesopelagos net with a mouth opening of $5 \times 7 \mathrm{~m}$ and a total length of $58 \mathrm{~m}$, tracked by a cable. Temperature, conductivity, pressure, dissolved oxygen and fluorescence were recorded by a Seabird 911Plus conductivity temperature depth (CTD) profiler; with a mounted Dissolved Oxygen Sensor and Seapoint Chlorophyll Fluorometer Sensor. Different depth levels were established and samples were taken during the daytime and nightly. 38 different species were identified of 8 different families. Sergestidae and Euphausiidae were the most abundant and Acanthephyridae was the family that most contributed to the total biomass. Pelagic shrimp assemblages, related with latitudinal changes in biomass and abundance, agreed with previous delimitation of ecoregions in the Atlantic Ocean. Diel vertical migrations were detected along the transect, with a maximum of biomass within the oxygen minimum zone (OMZ) during the daytime. We estimated 158 millions tC of biomass of decapods, euphausiids and lophogastrids in the Atlantic Ocean.
\end{abstract}

